\title{
Kebijakan Pertumbuhan Industri dan Munculnya Masyarakat yang Anomi
}

\author{
Muhammad Hayat ${ }^{*}$ \\ hayato.hayat@gmail.com
}

\begin{abstract}
Abstrak
Kebijakan pembangunan Indonesia yang menekankan pada pertumbuhan telah tersirat pada pengembangan yang terkonsentrasi di wilayah perkotaan. Ini adalah efek dari ruang penyangkalan merebut modal di arena Darwin disebut sebagai "survival of the fittest." Ini adalah arena di mana persaingan sangat ketat dan kompetitif sehingga orang-orang yang kekurangan kemampuan akan dihilangkan. Dalam konteks masyarakat kota, orang-orang yang tidak memiliki apapun kemampuan kompetitif akhirnya akan menjadi kelompok marjinal. Selanjutnya, dalam piramida masyarakat kota, kelompok-kelompok marginal akan membangun komunitas baru yang pasti akan menghasilkan nilai-nilai baru dengan cara dan selera mereka sendiri. Sosiologis, dapat dipahami sebagai munculnya masyarakat dengan nilai-nilai "liyan".Industri dengan pertumbuhan sebagai fokus utamanya telah menciptakan jenis masyarakat anomali (yang membuat kelompok lain atau dirinya sendiri / dirinya tidak ada atau "liyan"). Anomali masyarakat telah direkam dari produksi kesadaran kolektif dengan kepentingan ekonomis sebagai orientasi utama. Ini akan memunculkan satu-dimensimasyarakat yang membuat modal mencari cara-cara hidup mereka dalam kehidupan. Bahkan kondisi ini telah menghilangkan ruang publik dalam komunikasi masyarakat.
\end{abstract}

Kata kunci: anomali masyarakat, kebijakan, pertumbuhan industri

\begin{abstract}
The policy of Indonesian development emphasizing on the growth has implied on the concentrated development in the city areas. It is the effect of the contesting space seizing capital is in the arena Darwin called as "survival of the fittest." It is an arena where competition is very tight and higly competitive so the ones who are lack of capability will be naturally eliminated. In the context of the city society, the ones who don't possess any competitive ability will finally become the marginal groups. Next, in the pyramid of city society, those marginal groups will build a new community who will surely produce the new values with their own ways and tastes. Sociologically, it is understood as the emergence of society with truly "liyan" values of the natural pyramid of the city society before the urbanisation waves happen. Industrial growth emphasizing on the economic growth has implied on how an individual or a group interact with others. Then the main building of the interactions will finally come to economical interests and the non-existence of the human values. At the end the common spaces which are built together will always be in the economical perspective.
\end{abstract}

Key words: anomalous society, industrial growth, policy

\section{Pendahuluan}

Kebijakan pembangunan Indonesia yang menitikberatkan pada pertumbuhan ekonomi berimplikasi pada terkonsentrasinya pembangunan di wilayah

*Korespondensi : Muhammad Hayat. Prodi Sosiologi FISIP UMM , J1 Raya Tlogomas 246 Malang (0341) 464318 Fax (0341) 460435. 
perkotaan. Konsekuensinya, terjadi ketimpangan ekonomi antara Desa dan Kota. Struktur ekonomi akhirnya lebih didominasi oleh industri dan jasa. Struktur ekonomi yang berubah sudah barang tentu memberi pengaruh yang sangat signifikan bagi penurunan jumlah tenaga kerja di sektor pertanian.

Tabel 1. Pangsa Sektor Pertanian terhadap Perekonomian Indonesia (\%)

\begin{tabular}{|l|l|l|l|l|l|l|}
\hline & $\mathbf{1 9 7 5}$ & $\mathbf{1 9 8 5}$ & $\mathbf{1 9 9 5}$ & $\mathbf{1 9 9 6}$ & $\mathbf{1 9 9 8}$ & $\mathbf{2 0 0 8}$ \\
\hline $\begin{array}{l}\text { Struktur } \\
\text { Perekonomian }\end{array}$ & \multicolumn{7}{|l|}{} \\
\hline Pertanian & 30,02 & 23,2 & 16,2 & 15,4 & 15,2 & 13,7 \\
\hline Industri & 33,5 & 35,9 & 39,1 & 40,0 & 42,0 & 42,0 \\
\hline Jasa & 36,3 & 40,9 & 44,7 & 44,6 & 41,0 & 35,0 \\
\hline $\begin{array}{l}\text { Pangsa } \\
\text { Tenaga Kerja }\end{array}$ & & & & & & \\
\hline Pertanian & 62,0 & 56,0 & 48,0 & 46,0 & 45,0 & 40,3 \\
\hline Sektor lain & 38,0 & 44,0 & 52,0 & 54,0 & 55,0 & 59,7 \\
\hline
\end{tabular}

Data tersebut menunjukkan jika struktur perekonomian pada tahun 2008 sangat didominasi oleh sektor industri dan jasa yang menyumbang $77 \%$ pada struktur perekonomian. Sementara pertanian hanya 13,7\%. Penurunan yang sangat tajam dalam struktur perekonomian di bidang pertanian menunjukkan begitu bernafsunya pemerintah untuk mengumpulkan pundi-pundi kapital dari sektor jasa dan industri. Dalam pandangan pemerintah dengan menggenjot sektor industri dan jasa maka akan semakin banyak devisa yang diterima. Kebijakan tersebut sangat membantu kelancaran program-program pembangunan. Sebuah logika yang pada awalnya cukup berjalan dengan mulus (Mudrajad Kuncoro, 2011).

Dominasi industri dan jasa dalam ekonomi Indonesia pada dasarnya berhubungan secara langsung dengan semakin terjerembabnya pangsa tenaga kerja pertanian. Berdasakan tabel tersebut menunjukkan bahwa pangsa tenaga kerja pertanian mengalami penurunan yang sangat drastis selama kurun 33 tahun yaitu dari 62,0\% pada tahun 1975 menjadi 40,3\% pada tahun 2008. Sementara sektor lain bergerak sangat signifikan yaitu dari 38,0\% pada tahun 1975 menjadi 59,7\% pada tahun 2008. Angka-angka yang sangat memprihatinkan jika menelisik bahwa sejarah pertanian sejatinya tidak bisa dilepaskan dari republik ini. Angka-angka tersebut juga menunjukkan jika di Desa potensi pekerjaan semakin lama semakin menipis (jika tidak mau dibilang tidak ada). Angka-angka tersebut bisa juga dipahami bahwa tidak 
ada itikad baik dari pemerintah untuk menempatkan pertanian sebagai prioritas utama pembangunan padahal sebagian besar penduduk Indonesia tinggal di Desa.

Marjinalisasi Desa berimplikasi sangat besar bagi penghuninya. Manakala pekerjaan pertanian semakin tidak bisa diandalkan untuk menopang kehidupan, mulailah terlintas untuk mencari penghidupan yang lebih layak di tempat lain. Kota menjadi tujuan utama para pencari kerja dari Desa. Kisah sukses orang Desa yang merantau ke Kota menjadi cambuk yang semakin membulatkan orang Desa untuk mengais rejeki di kota. Menurut Herlianto, ada dua faktor interaktif yang mendorong lajunya proses urbanisasi, yaitu faktor pendorong (push) dan faktor penarik (pull). Kurangnya fasilitas untuk hidup dan pendidikan, makin menyempitnya kemungkinan berusaha di Desa dan terhisapnya hasil-hasil pedesaan yang dimanfaatkan bagi pembangunan di kota-kota besar mendorong orang meninggalkan desanya untuk mencari kesempatan kenikmatan hidup yang lebih baik di kota-kota besar $(1997 ; 14)$. Inilah awal mula urbanisasi yang menyerbu Kota dan mengalami pergerakan dengan sangat cepat.

Kota pada akhirnya tidak punya kemampuan menampung gelombang kedatangan manusia yang mengadu peruntungan ekonomi. Kota di Indonesia, Sebagai sebuah Kota bekas jajahan Belanda, desain yang sengaja dibuat oleh Belanda adalah Kota dengan prototipe untuk kepentingan legitimasi politik. Oleh karena itu menggagas Kota dengan konsep industri pada dasarnya adalah menegasikan apa yang selama ini berkembang dalam relasi utama masyarakat. Kota- kota di Indonersia pada akhirnya tidak mempunyai kemampuan secara alamiah untuk menjadi Kota dengan basis utama industri.

Tingginya mobilitas penduduk Desa yang bergerak secara sporadis ke Kota untuk bersaing memperebutkan kue ekonomi bermuara pada logika alamiah sebuah persaingan yaitu yang tidak punya kemampuan kompetitif dengan sendirinya tersingkir. Dalam bahasanya Charles Darwin, terjadilah seleksi alam. Hal tersebut akibat dari ruang berkontestasi memperebutkan kapital ada di arena yang menurut Charles Darwin digambarkan sebagai "survival of the fittest". Sebuah arena dimana pertarungan terjadi sangat kompetitif, maka dengan sendirinya yang tidak punya kemampuan akan tersingkir. Dalam konteks masyarakat Kota, yang tidak punya kemampuan kompetitif akhirnya menjadi kelompok terpinggirkan. Selanjutnya dalam 
piramida masyarakat Kota, masyarakat yang terpinggirkan ini menjadi komunitas baru yang memproduksi nilai baru dengan cara dan cita rasa mereka. Secara sosiologis, dipahami sebagai munculnya masyarakat dengan nilai-nilai yang benar-benar liyan dari piramida alamiah masyarakat kota sebelum terjadinya gelombang urbanisasi.

Pembangunan industri dengan fokus pada pertumbuhan ekonomi berimplikasi pada cara individu atau kelompok berinteraksi dengan individu atau kelompok lain. Bangunan utama interaksi muara akhirnya adalah interest ekonomi dan menidakkan nilai buman. Pada akhirnya ruang bersama yang dibangun selalu ditarik dalam perspektif ekonomi. Industri dengan tangan utamanya pertumbuhan melahirkan kelompok masyarakat yang anomi (me-liyan-kan kelompok lain atau dirinya sendiri).

\section{Pembahasan}

Tulisan ini mencoba memfokuskan pada anomi yang terjadi pada masyarakat perkotaan. Masing-masing kelompok masyarakat akhirnya menjadi entitas sendiri yang mencoba menidakkan kelompok masyarakat lain. Produksi nilai dengan penguatan kolektivitas kelompok berujung pada semakin hilangnya ruang bersama antara kelompok masyarakat.

\section{Anomi Masyarakat Kota}

Menurut Emile Durkheim, anomi merujuk pada hilangnya norma dan aturan yang membimbing dalam kehidupan sosial sehari-hari (Richard Osborn:1999 halaman 41). Ketika masyarakat sudah tidak ada aturan bersama pada saat tersebut sejatinya masing-masing individu atau kelompok sosial akan mencoba untuk memproduksi nilai maupun custom yang menidakkan kelompok yang lain. Pada kasus Indonesia, kebijakan pembangunan dengan fokus pertumbuhan industri pada akhirnya yang diproduksi adalah dunia material. Penanda identitasnya adalah kepentingan ekonomi.

Masyarakat semacam ini akan memproduksi solidaritas dalam ranah solidaritas mekanik yang bercampur dengan solidaritas organik. Campuran solidaritas tersebut pusaran utamanya tetap untung rugi. Solidaritas mekanik diproduksi agar bisa bertahan dalam persaingannya dengan kelompok lain. Sementara solidaritas organik diproduksi sebagai cara untuk menghadapi kenyataan hidup yang semakin 
kompetitif. Dalam perspektif Charles Darwin hidup mereka ada dalam arena survival of the fittest (bertahan dalam persaingan yang sangat kompetitif). Solidaritas mekanik yang dibangun oleh masyarakat adalah membangun kesadaran kolektif.

\section{Kesadaran Kolektif}

Kesadaran kolektif sebagai suatu kesadaran bersama yang mencakup keseluruhan kepercayaan dan perasaan kelompok, dan bersifat ekstern serta memaksa (Kamanto Sunarto:2000 halaman 132). Terkonsentrasinya kue ekonomi di daerah perkotaan berimplikasi terjadinya gelombang urbanisasi besar-besaran ke Kota. Ketidakmampuan Kota memberi kesejahteraan terhadap pendatang berimplikasi pada sporadisasi Kota menjadi beragam kelompok sosial. Masing-masing kelompok sosial tersebut akan membangun identitas kelompoknya dengan menguatkan ikatan kolektif diantara mereka. Ikatan kolektif akansemakin memperkuat cara mereka mendefinisikan kelompoknya dengan cara dan budaya yang mereka bangun sendiri. Menurut Robert K. Merton diantara kelompok tersebut pada dasarnya sedang terjadi pola interaksi yang saling mendefinisikan. Dimana ada tiga kriteria objektif bagi suatu kelompok. Pertama, kelompok ditandai oleh sering terjadinya interaksi. Kedua, pihak yang berinteraksi mendefinisikan diri mereka sebagai anggota. Ketiga, pihak yang beinteraksi didefinisikan oleh orang lain sebagai anggota kelompok (Kamanto Sunarto:2000 halaman131).

Pendefinisian tersebut mau tidak mau tidak bisa dilepaskan dari kelompok status dan peran yang mereka miliki. Status sebagai pedagang kaki lima maka identifikasi solidaritas adalah dengan pedagang kaki lima yang lain. Status sebagai pengamen identitas solidaritas yang dibangun pun dengan pengamen yang lain. Status sebagai anak jalanan, identitas solidaritas yang diproduksi, sinergitasnya juga dengan anak jalanan lainnya. Dan masih banyak lagi contoh lainnya. Bangunan solidaritas yang seperti ini mengakibatkan masing-masing kelompok sosial akan semakin mengerucutkan nilai-nilai kelompoknya. Kesadaran kolektif yang dibangunpun lebih mengedepankan dalam ruang material. Sehingga wujud material menjadi cara mereka berinteraksi dengan individu lain dalam kelompok sosial tersebut. Wujud material tersebut menjadi lebih penting dibanding penanda status yang lain.

\section{In-Group dan Out-Group}


Kesadaran kolektif yang dibangun dalam produksi material sejatinya juga menidakkan individu yang tidak punya kemampuan untuk bertahan dalam status dan peran dalam kelas status mereka. Pada akhirnya mereka juga akan ter-liyan-kan oleh struktur dalam kelompok sosial tersebut. Inilah yang dikatakan Sumner sebagai kondisi in-group dan out-group. Dalam tafsir sosiologis, semakin tingginya produksi kesadaran kolektif dari sebuah kelompok sosial berimplikasi pada semakin tinggi pula kemampuan sebuah kelompok sosial untuk menidakkan kelompok sosial yang lain. Semakin terlekat kesadaran kolektif sebuah kelompok sosial, keberfungsian konsep memusuhi terhadap kelompok sosial lainnya semakin menemukan muaranya.

Menurut Sumner di kalangan anggota kelompok dalam (in-group) dijumpai persahabatan, kerjasama, keteraturan dan kedamaian sedangkan hubungan dengan kelompok luar (out-group) cenderung ditandai kebencian, permusuhan, perang dan perampokan (Kamanto Sunarto:2000 halaman 134). Kondisi semacam ini semakin terlihat sebab yang diperebutkan adalah ruang-ruang ekonomi yangh spacenya semakin sedikit. Konflik antar pedagang kaki lima dengan pengambil kebijakan Kota menunjukkan kepada kita bahwa menidakkan kelompok lain menjadi cara mereka mempertahankan diri dari kerasnya kompetisi. Konflik antara beragam gank yang tumbuh subur di perkotaan memperlihatkan kepada kita bahwa me-liyan-kan kelompok lain adalah cara bagaimana sebuah kelompok sosial mempertahankan status dan perannya dalam masyarakat. Masih banyak contoh konflik di perkotaan yang menunjukkan kepada kita jika menidakkan kelompok sosial lain adalah cara sebuah kelompok untuk bisa tetap mempertahankan diri.

Masih menurut Sumner, perasaan yang berkembang pada masyarakat modern ialah patriotism. Meskipun dalam masyarakat modern batas kelompok telah diperluas dan keanggotaan yang dijadikan acuan ialah kewarganegaraan, namun dalam patriotisme kesetiaan pada kelompok dan pimpinan kelompok serta perasaan etnosentrisme tetap dipertahankan. Setiap warga negara diharapkan berkorban untuk negaranya. Dalam pandangan Sumner patriotisme ini bahkan dapat berkembang menjadi chawvinism (Kamanto Sunarto:2000 halaman 135).

Merujuk pada kelompok sosial masyarakat kota, dalam tafsir sosiologis patriotism dibangun untuk memperkuat kesadaran kelompok sehingga nilai-nilai bersama dijadikan cara bergerak bagi individu yang ada di dalam kelompok sosial 
tersebut. Patriotisme bisa dipahami sebagai kemampuan sebuah kelompok sosial memproduksi kebanggaan kelompok sosial. Kebanggaan yang pada akhirnya dapat berkembang pada totalitas untuk berkorban terhadap nilai kelompok sosial-nya. Kondisi semacam ini berimplikasi pada munculnya konflik sosial antar kelompok sosial. Anomi terhadap kelompok lain menjadi cara mereka memandang kelompok lain.Dalam pandangan Georgee Simmel setiap individu atau kelompok sosial pada akhirnya akan memproduksi hostile feeling, dimana individu yang mengalami interaksi saling bermusuhan. Bentuknya adalah kebencian dan kecemburuan, keinginan dan nafsu (Novri Susan:2009).

Melihat fenomena perkotaan di Indonesia, kota seringkali hanya diperuntukkan bagi yang mempunyai capital. Hal tersebut bermuara pada kebencian dan kecemburuan. Keinginan dan nafsu bisa terlihat dari produksi etalase dunia material yang tersebar sedemikian luas sampai ke pelosok desa sehingga stock of knowledge yang terbangun hanya ingatan akan dunia etalase. Berikut ilustrasi dari dunia renyah budaya modernitas.

"Seorang bapak yang berasal dari sebuah Desa yang baru saja mempunyai sepeda motor keluaran terbaru, pada waktu libur, bersama keluarganya pergi jalan-jalan ke kota. Bersama istri dan dua anaknya yang berumur 4 dan 8 tahun mereka merencanakan pergi ke tempat wisata di pusat Kota. Baru dua kilo meter meninggalkan desanya, di kiri jalan mata mereka sudah disuguhi pemandangan indah yaitu sebuah cafe dengan tatanan interior yang menarik. Stock of Knowledge mengisi ruang memori keluarga tersebut tentang bagaimana mengkonsumsi sebuah makanan dengan cara baru. Dalam perjalanan selanjutnya mereka juga bertemu dengan ritel-ritel modern seperti Alfa Mart, Indo Maret maupun Alfa Midi. Etalase konsumsi yang sejatinya adalah ruang kuasa kapitalisme terhadap negara berkembang mereka cerna sebagai kemudahan berbelanja. Lagi-lagi stock of knowledge tentang konsumsi menghegemoni ruang pikir keluarga tersebut. Belum hilang ingatan mereka tentang dunia konsumsi baru, lagi-lagi di jalan mereka berkenalan kembali dengan dunia konsumsi. Kali ini mengatasnamakan keluarga. Slogannya berbunyi seperti ini "Ingin senang-senang satu keluarga, datanglah ke Water Park". Water Park yang sejatinya adalah "air" coba dikomodifikasikan dalam ruang senang keluarga. Padahal keluarga tersebut setiap hari juga melihat sungai dengan airnya yang melimpah ruah. Tetapi kelihaian budaya konsumsi, menjadikan air di water park ada di kelas status atas, sementara air di sungaisungai belakang rumah tetap bersahaja sebagai sumber kehidupan bagi sawahsawah. Oleh dunia konsumsi, air dikonstruksi sebagai penambah cita rasa status. Lagi-lagi keluarga tersebut mempunyai stock of knowledge yang berhubungan dengan budaya konsumsi.

Ingatan tentang dunia konsumsi semakin menggila masuk ke ranah pikir keluarga tersebut, manakala di perempatan traffic light menunjukkan lampu merah, seketika seluruh kendaraan berhenti. Pada saat itu keluarga tersebut 
melihat banyak sekali mobil-mobil bagus antri menunggu lampu berubah hijau. Seperti show room mobil. Lagi-lagi pelajaran konsumsi yang mereka pelajari. Saat menunggu, kebetulan samping sepeda motor mereka adalah sebuah mobil keluaran baru dengan jendela yang dibuka. Dari dalam mobil terlihat penumpangnya sedang asyik menelpon menggunakan HP mahal yang warnanya menyolok. Lagi-lagi pelajaran konsumsi menjadi ranah utama liburan keluarga tersebut. Pelajaran berharga tentang bagaimana mempelajari aneka satwa di kebun binatang atau pengatahuan baru di museum akhirnya berkelindan dengan budaya konsumsi".

Ilustrasi tersebut menunjukkan jika budaya konsumsi sudah menyeruak sedemikian masif masuk ke masyarakat-masyarakat pinggiran kota, bahkan sangat mungkin sampai ke pelosok desa. Masyarakat ter-anomi-kan dari dirinya dan lingkungannya. Keinginan dan nafsu telah terkerangkeng dalam dunia renyah budaya modernitas. Perilaku menidakkan dalam pandangan Lewis Coser dapat memunculkan hostile behaviour yang bisa mengakibatkan masyarakat dalam situasi konflik (Nofri Susan:2009). Sumber konflik bersifat material yang mewujud dalam perebutan sumber-sumber ekonomi. Masing-masing kelompok sosial akan membangun solidaritasnya bagi kepentingan konflik dengan kelompok lain. Dan jika diperlukan membangun aliansi dengan kelompok lain. Konflik sosial seiring dengan pertumbuhan industri sejatinya menempatkan setiap kelompok sosial untuk menganomi-kan dirinya, kelompoknya maupun kelompok lain.

\section{Masyarakat Satu Dimensi}

Film Gangs of New York, memperlihatkan dengan sangat jelas bagaimana masing-masing kelompok sosial berusaha membangun solidaritasnya sendiri-sendiri. Film yang mengambil latar pada pertumbuhan awal New York sebagai kota industri tersebut memberikan gambaran secara jelas kepada kita bahwa masing-masing kelompok mencoba mempertahankan diri. Jika memang diperlukan, konflik terbuka dengan kelompok lain adalah jalan terbaik untuk mempertahankan diri. Dalam film yang dibintangi oleh Leonardo Dicaprio, Daniel Day-Lewis dan Cameron Diaz tersebut konflik sosial yang terjadi pada dasarnya adalah perebutan kue ekonomi yang semakin menyempit. Dalam perspektif sosiologi ruang, ruang merupakan kekuasaan dari mereka yang mempunyai kekuatan kapital. Oleh karena itu bisa dipahami jika pada akhirnya pengaplingan ruang diperkotaan hanya untuk kepentingan penguasa 
kapital. Sebagai contoh lokasi yang seharusnya untuk daerah resapan air, dibelokkan peruntukannnya untuk pembangunan perumahan mewah. Lokasi yang seharusnya untuk daerah pendidikan, dengan berbagai cara akhirnya terlegitimasi menjadi pusat bisnis. Hal ini terjadi disebabkan ekonomi menjadi cara utama kelompok sosial mempertahankan dirinya. Kasus Indonesia juga menunjukkan wajah yang sama.

Kondisi semacam ini menjadikan manusia telah kehilangan ruang yang paling strategis dari diri manusia yaitu ruang human. Human yang dipahami sebagai cara manusia menghargai segala keseimbangan nutrisi hidup mengalami desaklarisasi yang luar biasa akut saat diri atau kelompok terdampar dalam ruang ekonomi semata. Dalam bahasa Herbert Marcuse kondisi seperti ini dipahami sebagai one dimentional man atau masyarakat satu dimensi (Herbert Marcuse:2000).

Menurut Herbert Marcuse, ruang pribadi ini telah dilanggar dan dilelehkan oleh realitas teknologi. Produksi massa dan distribusi massa mengklaim individu secara keseluruhan dan psikologi industri sudah sejak lama berhenti untuk dibatasi oleh pabrik. Proses-proses bermacam-macam dari introjeksi (penggabungan) tampak menjadi kaku pada hampir seluruh reaksi-reksi mekanis. Hasilnya adalah, bukan penyesuaian tetapi mimesis. Suatu identifikasi langsung dari individu dengan masyarakat-nya, akhirnya melalui hal itu, dengan masyarakat secara keseluruhan (Sylvester G. Sukur dan Yusup Priyasudiarja:2000 halaman 15).

Gagasan dari Herbert Marcuse sejatinya ingin menunjukkan kepada kita jika teknologi telah menjadi dimensi yang mengerucutkan manusia pada pencarian maksimal hasil-hasil teknologi. Wujudnya adalah produksi modernitas. Dalam keseharian, kita bisa melihatnya dari etalase dunia komsumtif. Satu dimensi tersebut adalah sisi material dari modernitas. Manusia dalam pola interaksinya yang lebih dikedepankan adalah kepentingan ekonomi semata. Masyarakat satu dimensi (one dimentional man) pada dasarnya meng-anomi-kan manusia dari sisi yang paling berharga bagi manusia yaitu sisi buman.

Max Weber, salah satu tokoh penting dalam tradisi Sosiologi Klasik mengatakan jika kelompok sosial tersebut sedang terjebak dalam iron cage atau sangkar besi modernitas (Georgee Ritzer:2004). Iron cage pada dasarnya adalah ketidakmampuan manusia untuk keluar dari apa yang dihasilkannya, yaitu produkproduk modernitas. Produk tersebut bukannya membebaskan manusia dari objeknya 
(hasil-hasil modernitas), tetapi justru menguasai subjek (manusia). Kondisi dimana manusia tidak punya kemampuan untuk keluar dari kerangkeng besi objek (hasil modernitas). Pada akhirynya masyarakat ter-anomi-kan dari dirinya.

Gagasan Max Weber tersebut dikuatkan oleh pernyataan Anthony Giddens bahwa modernitas sebagai sebuah juggernaut (panser raksasa). Menurut Anthony Giddens dalam Georgee Ritzer bahwa kehidupan kolektif modern ibarat panser raksasa yang tengah melaju hingga taraf tertentu bisa dikemudikan, tetapi juga terancam akan lepas kendali hingga menyebabkan dirinya hancur lebur. Panser raksasa ini akan menghancurkan orang yang menentangnya dan meski kadang-kadang menempuh jalur yang teratur, namun ia juga sewaktu-waktu dapat berbelok ke arah yang tak terbayangkan sebelumnya (Georgee Ritzer:2004 halaman 553).

Pernyataan dari Anthony Giddens pada dasarnya menunjukkan bahwa hilangnya bumanisme memungkinkan manusia melakukan apa saja lewat kuasanya terhadap kapital. Pada saat bersamaan, penguasaan terhadap kapital juga berimplikasi pada sesuatu yang tidak terbayangkan manusia, yaitu ketidakmampuan mengendalikan kapital. Hasil akhirnya manusia justru terkerangkeng oleh ka;pital, laksana panser raksasa yang lepas kendali. Hal tersebut bermuara pada masyarakat ter-anomi-kan dari dirinya.

\section{Hilangnya Ruang Publik}

Menurut Jurgen Habermas ruang publik atau public sphere dipahami sebagai suatu wilayah kehidupan sosial kita dimana apa yang disebut opini publik terbentuk akses kepada ruang publik terbuka bagi semua warga negara. Sebagian dari ruang publik terbentuk dalam setiap pembicaraan dimana pribadi-pribadi berkumpul untuk membentuk suatu publik. Bila publik menjadi besar, komunikasi ini menuntut suatu sarana untuk diseminasi dan pengaruh; zaman sekarang surat kabar dan majalah, radio dan televisi menjadi media ruang publik (Budi Hardiman:2010 halaman 270).

Definisi Jurgen Habermas tersebut, poin pentingnya adalah liberasi individu sebagai sebuah keniscayaan dalam ruang publik. Dengan begitu warga negara harus diperhatikan hak-nya oleh penguasa ruang publik. Ada komunikasi dua arah, dimana hasil dari komunikasi tersebut pada dasarnya adalah hasil kesepakatan 
bersama antara anggota masyarakat warga. Jurgen Habermas menyebutnya sebagai komunikasi tanpa domiasi. Menurut M. Sastrapratedja, ruang publik bukan suatu institusi atau organisasi politik, tetapi suatu ruang tempat warganegara terlibat dalam deliberasi dialogal mengenai isu publik (Budi hardiman:2010 halaman 270). Penekanan pada keterlibatan warga dalam deliberasi sejatinya ingin menunjukkan jika masyarakat warga pada dasarnya adalah "berdaya"

Modernitas menghilangkan banyak ruang publik karena pada akhirnya ruang publik cuma dikuasai oleh sekelompok individu tertentu yang menguasai ruang publik. Biasanya mereka adalah penguasa kapital dan pengambil kebijakan. Menurut M. Sastrapratedja, menyempitnya ruang publik terjadi dalam dua tataran, yaitu tatanan negara yang semakin mengalami rasionalisasi, khususnya birokratisasi (sebagaimana digambarkan Max Weber) dan masyarakat yang terfragmentasi ke dalam kepentingan individual (sebagaimana digambarkan Hobbes) (Budi Hardiman:2010Halaman 273)

Merujuk dari kebijakan pembangunan Indonesia yang memfokuskan pada pertumbuhan industri pada dasarnya adalah memberi keleluasaan yang luar biasa kepada pemerintah untuk melakukan rasionalisasi dalam setiap kebijakan pembangunan. Rasionalisasi birokrasi berarti birokrasi dijadikan alat oleh pemerintah untuk melegitimasi setiap kebijakan yang dikeluarkannya. Atas nama pembangunan, kearifan lokal dihilangkan dan diganti dengan birokrasi yang menidakkan fungsi lokalitas. Atas nama pembangunan, sumber daya alam dilokalisir untuk kepentingan pusat dengan mengeluarkan banyak sekali aturan-aturan yang semakin meneguhkan dominasi pusat atas daerah. Rasionalisasi akhirnya mengubah negara sebagai apparatus yang cuma mencari keuntungan untuk kepentingan dirinya. Dalam pemahaman Althusser, negara telah menjadi State of Apparatus yang dengan kuasa legitimasinya semua harus tunduk kepada apparatus (negara). Rasionalisasi Freeport, Newmont, dan lain sebagainya menunjukkan dominasi negara dalam ruang publik.

Ruh ruang publik yang menempatkan masyarakat warga dalam liberasi dialogal akhirnya kehilangan nyawanya karena semua telah dirampas oleh negara. Negara kehilangan sisi buman-nya. Masyarakat pada akhirnya juga belajar untuk menjadi apparatus seperti yang diajarkan oleh negara. Masyarakat juga akhirnya belajar untuk melihat sesuatu dari sisi material. Ruang publik hilang seiring ter-anomi-nya masyarakat oleh ulah negara. 
Masyarakat yang terfragmentasi dalam kepentingan individual merujuk dari apa yang dikatakan oleh Thomas Hobbes, memberi gambaran secara jelas kepada kita bahwa ruang homo bomini lupus sepertinya menemukan muaranya di negara Indonesia yang menempatkan kebijakan pertumbuhan industri sebagai prioritas pembangunan. Model pembanguan seperti ini, menjadikan ruang publik cuma milik individu yang mempunyai kemampuan menguasai faktor produksi (kapital, sumber daya manusia dan sumber daya alam). Penguasan tersebut menjadikan mereka sebagai homo homini lupus. Kelompok yang menguasai faktor produksi, dialah kelompok yang akan menguasai interest (kepentingan). Terlihat dengan jelas di Indonesia, penguasaan faktor produksi oleh segelintir orang menjadikan arah pembangunan cuma untuk kepentingan mereka semata. Pada akhirnya ruang publik pun dikuasai oleh penguasa kapital.

Kondisi yang menempatkan masyarakat warga dalam ketakberdayaan, pada saat tersebut sejatinya warga negara sudah tidak mempunyai fungsi. Menutrut M. sastrapratedja, ruang publik menciut, manakala warga negara lebih menekankan identitasnya sebagai konsumen daripada sebagai warga negara yang berpartisipasi dalam ruang publik (Budi Hardiman:2010 Halaman 275). Dalam kasus Indonesia, terlihat dengan jelas jika mall, Super Mall, Hotel mewah, dan thing mewah lainnya telah mulai menghilangkan ruang publik. Dengan kata lain, masyarakat telah teranomi-kan oleh lingkungannya.

Menurut George Simmel modernitas telah memunculkan aroma individualitas. Semakin banyak institusi-institusi menuntut otonomi semakin kecil ruang individu untuk mengekspresikan kreatifitas kebudayaannya (AB. Widyanta: 2004 halaman 144). Terlihat jelas bahwa birokratisasi bermuara pada tuntutan institusi formal untuk menguatkan legitimasinya. Hasil akhirnya masyarakat warga tidak mempunyai kemampuan untuk mendiskusikan ide-idenya. Kebijakan pertumbuhan industri di Indonesia mengakibatkan masyarakat seakan cyborg yang hanya bergerak sesuai titah remote-nya.

George Simmel juga mengatakan bahwa semakin besar kreatifitas kebudayaan menemukan saluran ekspresi individualistik maka semakin banyak sistem kebudayaan tertumpuk menjadi artefak-artefak tak bernyawa (kehilangan vitalitasnya), karena terputus dari daya kreatif individu-individu (AB. Widyanta:2004 halaman 144). 
Keadaan ini menunjukkan jika kebudayaan dalam ranah modernitas hanya diproduksi sebagai kepentingan budaya konsumsi saja sehingga uniformitas menjadi rejim baru yang meluluhlantakkan kreatifitas individu. Kebudayaan pada akhirnya kehilangan ruhnya. Manakala kebudayaan kehilangan ruh-nya sejatinya masyarakat dan negara sedang memproduksi anomi-anomi. Masyarakat tercerabut dari dirinya dan anomi menjadi rejim baru yang siap meluluhlantakkan nilai buman. Dalam kasus Indonesia, Kebijakan pertiumbuhan industri telah mencerabut individu dan masyarakat dari ruang human-nya. Pada akhirnya yang tumbuh subur adalah anomi.

\section{Kesimpulan}

Kebijakan pembangunan Indonesia yang menekankan pada pertumbuhan industri berimplikasi pada hilangnya ruang buman masyarakat. Anomi masyarakat terekam dari produksi kesadaran kolektif yang orientasi utamanya adalah interest ekonomi. Implikasi akhirnya adalah munculnya masyarakat satu dimensi yang menjadikan pencarian kapital sebagai cara mereka mempertahankan hidupnya. Kondisi semacam ini menghilangkan ruang publik dalam aras komunikasi masyarakat warga.

Kebijakan pembangunan seharusnya memberikan ruang yang cukup bagi individu untuk mengekspresikan nilai buman-nya sehingga ruang publik dengan semangat liberasi dialogal bisa terproduksi, dan pada akhirnya masyarakat yang anomi lama kelamaan akan mengalami derajat penurunannya.

\section{Daftar Pustaka}

Widyanta, A.B. 2002.Problem Modernitas Dalam Kerangka Sosiologi Kebudayaan George Simmel. Yogyakarta: indelaras Pustaka Rakyat Cerdas

Hardiman, Budi F. 2010. Ruang Publik, Melacak "Partisipasi Demokratis" dari Polis sampai Cyberspace. Yogyakarta: Kanisius

Herlianto. 1997.Urbanisasi, Pembangunan, dan Kerusuban Kota. Bandung: Penerbit Alumni

Kuncoro, Mudrajat. 2010. Ekonomika Pembangunan. Jakarta: Erlangga

Loon, Borin Van dan Richard Osborn. 1999. Mengenal Sosiologi for Beginners. Bandung: Mizan 
Manning, Chriss dan Tadjuddin Noer Effendi. 1996.Urbanisasi, Pengangguran, dan Sektor Informal Kota. Jakarta: Yayasan Obor Indonesia

Rachbini, Didik J dan Abdul Hamid. 1994.Ekonomi Informal Perkotaan. Jakarta: LP3ES Ritzer,Georgee. 2004. Teori Sosiologi Modern. Jakarta:Prenada Media

Susan, Novri. 2009. Sosiologi Konflik dan Isu-Isu Konflik Kontemporer. Jakarta:Kencana

Sukur, Silvester G dan Yusup Priyasudiarja.2000.Manusia satu-Dimensi Herbert Marcuse. Yogyakarta: Yayasan Bentang Budaya

Sunarto, Kamanto. 2000. Pengantar Sosiologi. Jakarta:FEUI

Schoorl, J.W. 1988. Modernisasi Pengantar Sosiologi Pembangunan Negara-Negara Sedang Berkembang. Jakarta:Gramedia 